\title{
Role of vitamin D in chronic hepatitis C
}

\author{
Tae Yeob Kim \\ Department of Internal Medicine, Hanyang University Guri Hospital, Hanyang University College of Medicine, \\ Guri, Korea
}

\begin{abstract}
Vitamin D deficiency and a CYP27B1-1260 promoter polymorphism are associated with chronic hepatitis $\mathrm{C}$ and poor response to interferon-alfa based therapy.
\end{abstract}

Lange CM, Bojunga J, Ramos-Lopez E, von Wagner M, Hassler A, Vermehren J, Herrmann E, Badenhoop K, Zeuzem S, Sarrazin C.

J Hepatol 2011;54:887-893

The prevalence of hepatitis $\mathrm{C}$ virus (HCV) infection in adults over age 40 is $1.29 \%$, and the common $\mathrm{HCV}$ genotypes are $\mathrm{Ib}(40-59 \%)$ and $2 \mathrm{a}(33-52 \%)$ in Korea. ${ }^{1,2}$ The best predictor of long-term response for chronic hepatitis $\mathrm{C}$ $(\mathrm{CHC})$ to treatment is sustained virological response (SVR), defined as undetectable serum HCV RNA by PCR assay at 24 weeks after cessation of therapy. ${ }^{3}$ The standard of choice for $\mathrm{HCV}$ treatment is the combination of a pegylated interferon alpha and ribavirin (Peg/RBV). According to Korean data, the response rates to the recommended strategies have been observed to be high compared to Western data, but $20-40 \%$ of patients did not achieve an SVR. ${ }^{4-6}$ Two major predictors of SVR are genotypes and viral load. ${ }^{3}$ Other baseline predictors include the doses of Peg/RBV, gender, age, race, body weight, and fibrosis stage. ${ }^{3}$

Recently, two emerged predictors of response to antiviral treatment are interleukin-28B (IL-28B) rs12979860 C/T polymorphism and serum vitamin D concentration. IL-28B polymorphism is associated with SVR, and SVR rates are doubled in patients with the $\mathrm{C} / \mathrm{C}$ homozygotes compared with the carrier of the $\mathrm{T} / \mathrm{T}$ or $\mathrm{T} / \mathrm{C}$ alleles. ${ }^{7,8}$ However, this polymorphism represents a nonmodifiable factor that predicts SVR, and plays a smaller role in Korean patients due to high frequency of favorable allele. ${ }^{9}$ Pre-treatment serum vitamin D concentrations affect SVR, and vitamin D deficiency shows low SVR in Peg/RBV treatment. ${ }^{10,11}$ Clinicians have increasing interest in vitamin $\mathrm{D}$ because it is easily modifiable and its supplementation may improve response to antiviral treatment. ${ }^{12}$ Patients with $\mathrm{CHC}$ have higher incidence of severe vitamin D deficiency (25-hydroxyvitamin $\mathrm{D}, 25(\mathrm{OH}) \mathrm{D}<10 \mathrm{ng} / \mathrm{mL})$ compared to the normal control $(25 \%$ versus $12 \%, P<0.0001) .{ }^{13}$ The prevalence of vitamin D deficiency $(25(\mathrm{OH}) \mathrm{D}<20 \mathrm{ng} / \mathrm{mL})$ was $47.3 \%$ of males and $64.5 \%$ of females, ${ }^{14}$ but there was no report on that in patients with CHC in Korea.

Vitamin D, as a regulatory factor of phosphorus and calcium absorption in intestine and renal reabsorption of calcium, plays a role in calcium metabolism. Through hydroxylation process of liver and kidney, vitamin $\mathrm{D}$ from the skin and diet is converted into the major circulating form, $25(\mathrm{OH}) \mathrm{D}$, and then into the active form, 1,25 -dihydroxyvitamin $\mathrm{D}(1,25(\mathrm{OH}) \mathrm{D})$, respectively. ${ }^{15}$ In relation to vitamin $\mathrm{D}$ synthesis in the liver, mild to moderate liver dysfunction causes malabsorption of vitamin D and dysfunction of $90 \%$ or more results in inability to make sufficient

Keywords: Hepatitis C, chronic; Vitamin D; Sustained virologic response

\footnotetext{
Abbreviations: CHC, chronic hepatitis C; CYP, cytochrome P450; HCV, hepatitis C virus; IL, interleukin; Peg, pegylated interferon alfa; RBV, ribavirin; SVR, sustained virologic response; VDRs, vitamin D receptors; Th, helper T cell; 25(OH)D, 25-hydroxyvitamin D; 1,25(OH)D, 1,25-dihydroxyvitamin D

Comesponding author: Tae Yeob Kim

Department of Internal Medicine, Hanyang University Guri Hospital, 249-1 Gyomun-dong, Guri 471-701, Korea

Tel. +82-31-560-2177, Fax. +82-31-555-2998, E-mail; ktydoc@hanyang.ac.kr
} 
25(OH)D. ${ }^{15}$ Therefore, low vitamin D serum level in patients with $\mathrm{CHC}$ is correlated to severity of fibrosis. ${ }^{11}$ In addition to $\mathrm{CHC}, 25(\mathrm{OH}) \mathrm{D}$ serum level is an independent predictor of risk for cancer, autoimmune disease, cardiovascular disease, and metabolic disease. $^{15}$

$1,25(\mathrm{OH}) \mathrm{D}$ is activated by binding with the vitamin $\mathrm{D}$ receptors (VDRs), which are found in almost immune cells such as $\mathrm{CD}^{+}$and $\mathrm{CD}^{+} \mathrm{T}$ cells, B cells, neutrophils, and antigen presenting cells, and is an important mediator of innate immune and adaptive immune systems. ${ }^{16} 1,25(\mathrm{OH}) \mathrm{D}$ enhances chemotactic and phagocytic responses of macrophage as well as induces antimicrobial actions with the upregulation cathelicidin via VDRs. ${ }^{17}$ At the level of antigen presenting cells (like dendritic cells), 1,25(OH)D decreases antigen recognition by inhibited expression of MHC II molecules and co-stimulatory molecules (CD40, CD80, CD86). Furthermore, by suppressing production of IL-12 and IL-23, which are important Th1 and Th17 development, 1,25(OH)D inhibits the production of Th1 cytokines (IL-2 and IFN- $\gamma$ ) and Th17 cytokines (IL-17 and IL-23). A shift from Th1 to Th2 development stimulates Th2 cytokine production (IL-4). In addition, it induces regulatory $\mathrm{T}$ cells via modulation of dendritic cells and regulatory T cells and produce IL-10, which has the ability to interfere the development of the other Th subclasses. Finally, the action of $1,25(\mathrm{OH}) \mathrm{D}$ on B cells blocks proliferation, maturation to plasma cells, and immunoglobulin production. ${ }^{16}$

Petta et $\mathrm{al}^{11}$, by analyzing retrospectively a cohort of 197 patients, detected an association between lower vitamin $\mathrm{D}$ serum levels and failure to achieve SVR. Of different isoforms of cytochrome P450 (CYP) involved in vitamin D metabolism, CYP2R1 and CYP27A1 exist in liver and CYP27B1 exists in kidney. Levels of CYP27A1, but not CYP2R1, were directly related to vitamin serum $D$ levels and inversely correlated with necro-inflammation. ${ }^{11}$ Bitetto et $\mathrm{al}^{10}$ suggested that correction of vitamin D serum levels may play a complementary role to improve SVR in patients with difficult-to-treat HCV genotype and with IL-28B polymorphism. Based on the relationship between follow-up viral response rates and baseline $25(\mathrm{OH}) \mathrm{D}$ serum level, Bitetto et $\mathrm{al}^{10}$ suggested that vitamin D plays an important role in early HCV decline after antiviral treatment. In two reports about additional effect of vitamin D on SVR in patients with $\mathrm{CHC}, \mathrm{Abu}$ Mouth et $\mathrm{al}^{18}$ showed vitamin D supplementation to $\mathrm{Peg} / \mathrm{RBV}$ treatment significantly improved SVR in naïve genotype 1 patients ( $86 \%$ versus $43 \%, P<0.001$ ), and Bitetto et $\mathrm{al}^{12}$ showed the increase of SVR to antiviral treatment for recurrent hepatitis $\mathrm{C}(5 / 18$ versus $5 / 27, P<0.02)$. The latter two studies have limited value due to small number of patients.

Together with these studies, Lange et $\mathrm{al}^{13}$ retrospectively analyzed serum vitamin $\mathrm{D}$ levels and genetic polymorphisms in 468 naïve patients with CHC. As above mentioned, $25(\mathrm{OH}) \mathrm{D}$ is converted to the $1,25(\mathrm{OH}) \mathrm{D}$ by 1- $\alpha$-hydroxylase (CYP27B1) in the kidney and the biological activities of vitamin $\mathrm{D}$ are mainly mediated via the VDRs. Unlike other studies, ${ }^{10,11}$ subjects were investigated about correlation between polymorphisms within genes of vitamin D cascade (VDR and CYP27B-1260 promoter) and serum vitamin D levels. ${ }^{13}$ Three main findings are as follows. First, in similar to recent reports, the occurrence of vitamin D deficiency was more frequently observed in the patients $(66 \%)$ than in the controls (41\%). In addition, severe vitamin D deficiency was more observed in the patients (25\%) than in the controls (12\%). Second, pretreatment serum vitamin D level was related to high responsiveness of $\mathrm{Peg} / \mathrm{RBV}$ treatment in patients with HCV genotype 2/3, but not in patients with HCV genotype 1. This point is different from recent reports. Interestingly, in HCV genotype 1 patients, authors reported a positive association between SVR and 1- $\alpha$-hydroxylase promoter polymorphism (CYP27B1-1260) and they suggested that 25(OH)D serum levels might not be an optimal predictor of SVR. Therefore, further researches are needed to investigate the effect of vitamin D according to race, polymorphism, and genotypes. Third, SVR rates were significantly higher in patients with CYP27B1-1260 genotype AA or AC compared to CYP27B1-1260 genotype CC ( $77 \%$ and $65 \%$ versus $42 \%$, respectively; $P=0.02$ ), but VDR polymorphism is not associated with SVR. This study has some limitations due to retrospective data, absence of on-treatment vitamin $\mathrm{D}$ serum levels, and absence of potential confounders.

In conclusion, this study showed that the incidence of vitamin $\mathrm{D}$ deficiency is high in patients with $\mathrm{CHC}$, vitamin D serum levels is linked to SVR, and a CYP27B-1260 promoter polymorphism is related with poor response to $\mathrm{Peg} / \mathrm{RBV}$ treatment. To date, there are a few published reports on the role of vitamin D supplementation in patients with $\mathrm{CHC}$ and no domestic data on the relationship between vitamin $\mathrm{D}$ and $\mathrm{CHC}$. Adding vitamin D to standard interferon therapy may increase SVR rates without serious adverse events. However, to prove these findings, well designed and large prospective studies are needed. 


\section{REFERENCES}

1. Shin HR. Epidemiology of hepatitis $\mathrm{C}$ virus in Korea. Intervirology 2006;49:18-22.

2. Suh DJ, Jeong SH. Current status of hepatitis C virus infection in Korea. Intervirology 2006;49:70-75.

3. Ghany MG, Strader DB, Thomas DL, Seeff LB; American Association for the Study of Liver Diseases. Diagnosis, management, and treatment of hepatitis C: an update. Hepatology 2009;49:1335-1374.

4. Kang MJ, Jung EU, Park SW, Choi P, Kim JH, Park SJ, et al. Effects of pegylated interferon and ribavirin in Korean patients with chronic hepatitis C virus infection. Korean J Hepatol 2008;14:318-330.

5. Hwang SY, Lee HJ, Park KT, Kim KY, Lee SM, Park CW, et al. Effectiveness and complications of combination therapy with interferon alpha and ribavirin in patients with chronic hepatitis C. Korean J Gastroenterol 2007;49:166-172.

6. Lee H, Choi MS, Paik SW, Kim JH, Kim DY, Lee JH, et al. Peginterferon alfa-2a plus ribavirin for initial treatment of chronic hepatitis C in Korea. Korean J Hepatol 2006;12:31-40.

7. Ge D, Fellay J, Thompson AJ, Simon JS, Shianna KV, Urban TJ, et al. Genetic variation in IL28B predicts hepatitis C treatment-induced viral clearance. Nature 2009;461:399-401.

8. Thompson AJ, Muir AJ, Sulkowski MS, Ge D, Fellay J, Shianna KV, et al. Interleukin-28B polymorphism improves viral kinetics and is the strongest pretreatment predictor of sustained virologic response in genotype 1 hepatitis C virus. Gastroenterology 2010;139:120-129.

9. Sinn DH, Kim YJ, Lee ST, Gwak GY, Choi MS, Lee JH, et al. Association of a single nucleotide polymorphism near the interleukin-28B gene with response to hepatitis $\mathrm{C}$ therapy in Asian Patients therapy in Asian Patients. J Gastroenterol Hepatol 2011. doi: 10.1111/j.1440-1746. 2011.06744.x

10. Bitetto D, Fattovich G, Fabris C, Ceriani E, Falleti E, Fornasiere E, et al.
Complementary role of vitamin D deficiency and the interleukin-28B rs12979860 C/T polymorphism in predicting antiviral response in chronic hepatitis C. Hepatology 2011;53:1118-1126.

11. Petta S, Cammà C, Scazzone C, Tripodo C, Di Marco V, Bono A, et al. Low vitamin D serum level is related to severe fibrosis and low responsiveness to interferon-based therapy in genotype 1 chronic hepatitis C. Hepatology 2010;51:1158-1167.

12. Bitetto D, Fabris C, Fornasiere E, Pipan C, Fumolo E, Cussigh A, et al. Vitamin D supplementation improves response to antiviral treatment for recurrent hepatitis C. Transpl Int 2011;24:43-50.

13. Lange CM, Bojunga J, Ramos-Lopez E, von Wagner M, Hassler A, Vermehren J, et al. Vitamin D deficiency and a CYP27B1-1260 promoter polymorphism are associated with chronic hepatitis $\mathrm{C}$ and poor response to interferon-alfa based therapy. J Hepatol 2011;54: 887-893.

14. Choi HS, Oh HJ, Choi H, Choi WH, Kim JG, Kim KM, et al. Vitamin D insufficiency in Korea-a greater threat to younger generation: the Korea National Health and Nutrition Examination Survey (KNHANES) 2008. J Clin Endocrinol Metab 2011;96:643-651.

15. Holick MF. Vitamin D deficiency. N Engl J Med 2007;357:266-281.

16. Baeke F, Takiishi T, Korf H, Gysemans C, Mathieu C. Vitamin D: modulator of the immune system. Curr Opin Pharmacol 2010;10: 482-496.

17. Martineau AR, Wilkinson KA, Newton SM, Floto RA, Norman AW, Skolimowska $\mathrm{K}$, et al. IFN-gamma- and TNF-independent vitamin D-inducible human suppression of mycobacteria: the role of cathelicidin LL-37. J Immunol 2007;178:7190-7198.

18. Abu Mouch S, Fireman Z, Jarchovsky J, Assy N. Vitamin D supplement improves SVR in chronic hepatitis C (genotype 1) naive patients treated with peg interferon and ribavirin [Abstract]. J Hepatol 2010;52(Suppl 1):S26. 